Journal of Universal Computer Science, vol. 27, no. 5 (2021), 498-523

submitted: 30/11/2020, accepted: 30/3/2021, appeared: 28/5/2021 CC BY-ND 4.0

\title{
The effect of mobile and information technologies on the language development design of preschool children: a meta-analysis and meta-synthesis study
}

\author{
Duygu Mavi \\ (Near East University, Nicosia, Northern Cyprus \\ D https://orcid.org/0000-0003-0923-1553, maviduyguu@hotmail.com; dyumvi@gmail.com) \\ Filiz Erbay \\ (Near East University, Nicosia, Northern Cyprus \\ (1D https://orcid.org/0000-0002-9766-8570, filiz.erbay@neu.edu.tr, filizerbay42@gmail.com)
}

\begin{abstract}
This study aims to reveal the effect of mobile and information technologies (IT) supported education on the language development design of children, in different cultures in the preschool period, using the methods of meta-analysis and meta-synthesis. Fifteen (15) studies were examined in the meta-synthesis and 22 reviews in the meta-analysis. The studies reviewed in the meta-synthesis were subjected to content analysis, and codes were grouped under six themes. Taking into account the effect sizes reported in the experimental studies in the metaanalysis, the total effect size was calculated by using Comprehensive Meta-Analysis. The analysis revealed that mobile and IT supported education had a high positive effect on the language development of preschool children in different cultures.
\end{abstract}

Keywords: Mobile learning; Information Technology; language development; preschool; metaanalysis

Categories: L.1.0, L.3.0, L.3.6, L.5.1, K.3.1

DOI: $10.3897 /$ jucs.68942

\section{Introduction}

Preschool is a period in which the development of children is the fastest. Children are open to and eager for learning, and their interaction with the real world is intensified [Howard et al. 1991]. In this period, children seek for the ways to perceive their environment and the outside world. They try to make sense of the concepts that help them by interacting with their environment and they use the concepts they acquire in parallel with their language development.

Various studies were conducted to examine the factors associated with language development of learners. These studies revealed that these effects are associated with environmental factors, psychological characteristics of the environment [King et al., 1971], family structure and interest [Bus et al., 1995; Kiracioglu et al., 2019], socioeconomic level, demographic characteristics [Topping et al., 2011], gender [Chamot \& Keatley, 2004] language and literacy skills [Tabors et al., 2001], language education experiences [Hussein \& Albakri, 2019], motivation and attitude [Dörnyei, 2001; Gardner, 1985], language learning strategies [O'Malley \& Chamot, 1990], playing games and symbolic toys [Tomopoulous et al., 2006], spending time in the library or museum [Payne et al., 1994]. 
With the improvements in digital technology, the role of teachers in the "teaching and learning process" is changing too. Teachers who follow this projection, are more successful in skills such as counselling, leading and communicating with their students, and have better chances to achieve their targets [Ceker \& Uzunboylu, 2017]. Considering the prevalence of technology and its position in the life of individuals today [Mümtaz, 2001; Keser \& Semerci, 2019], it is seen that mobile and IT technologies have been used for the development of academic, social, cognitive and language skills since early childhood [Aitchison, 2018; Isik \& Jallad, 2019].

By using mobile and IT, students can actively use more than one sense organs, take part in an effective learning process, and therefore the duration of paying attention and interest may be longer [Celik \& Uzunboylu, 2020; Casper \& Theilheimer, 2010]. There are four critical steps in children's learning to maximize the use of mobile and IT and integrate mobile and IT into the educational process: the selection of the appropriate developmental program, the selection of the appropriate website, the integration of the program with the selected resources, and the selection of the appropriate mobile and IT to support learning experiences [Arnas, 2005; Kandır \& Alpan, 2008; Elsayed \& Salama, 2020]. This is with the inclusion of sign language images, picture communication boards, adapted books, and low-tech or high-tech audio output communication devices that parents and preschool teachers can use to support speech and language development in young children [Elgharnah \& Ozdamli, 2020; Dagyar, et al, 2020]. Mobile and IT helps in communication and language development [Skau \& Cascella, 2006]. The effects of these technological devices on language development in many areas of children's development, have been the subject of various studies.

The rapid development of technology [Karakaya, et al. 2017] and its involvement in educational processes brought with it the debate of mobile and its' effectiveness in learning and language development [Cavus, 2020]. Many researchers have tried to shed light on whether technology use is beneficial or harmful to the development of young children [McCarrick \& Xiaoming, 2007]. Children between the ages of 0-6 are in a critical period for learning, as they develop cognitive, language and social skills simultaneously. Therefore, it is important to understand the potential benefits and harms of technology on the development of these skills. Parette et al. (2010) argues that the integration of IT into the education process contributes to the development of basic literacy skills. Anagün et al. (2016) also stated that mobile and IT can be effective in the acquisition of many 21 st century skills, including language and communication skills. Using mobile and IT to acquire these skills could help children make progress in many areas of development [Blum et al., 2009; Ozcan \& Kert, 2020].

Mobile and IT supported education are provided for preschool children in different education systems. The meta-analysis study [Sung et al., 2016] done for investigating the effects of mobile devices on students' learning performances showed that mobile technology practices attracted the students' interests, increased their motivation for success, and improved their communication and collaboration skills. Aral [2006] found that the effect of computer-aided education was significant in the concept development of 6-year-old children attending kindergarten. Gülmez [2019] reported that the use of YouTube had a significant contribution to learning and speaking in preschool concepts. Nişan (2017) stated that technology-supported education contributed to the development of students' skills such as language development, problem solving, defining the problem and saying alternative ways. Toki and Pange (2010) found that 
computerized application software for use in e-learning activities helped to deal with speech problems and develop language learning of Greek preschool children.

Review of literature on mobile and IT pointed out that the studies examining the effects of mobile and IT on children language development are not quantitatively sufficient [Yakubu, et al., 2018; Ulubey \& Aykaç, 2017; Boe, 2013; Greenhill, 2010]. For this reason, it has made it necessary to start using mobile and IT in education environments in almost every region of the world [Demo et al., 2012; Goh \& Ali, 2014]. The development of social, emotional, cognitive and language features, which are considered important at all levels of education, has gained a special importance with the widespread use of technological opportunities and making them available in educational environments [Aral, 2006; Aitchison, 2018]. The use of technology in preschool education also ensures that education is scientific, current and contemporary [Aral, 2006; Günüç \& Atl1, 2017].

It is noteworthy that there are studies testing the effects of language gains [Aral, 2006; Acar \& Doğan, 2007; Karabulutlu, 2018; Özcan, 2018; Sung et al., 2016], and qualitative research examining the use of mobile and IT for the development of preschool children [İnci \& Kandır, 2017; Kocaman-Karoğlu, 2016; Gündoğan, 2014; Şahin, 2006; Uluser-İnan, 2003, as cited by İnci \& Kandır, 2017]. However, no metaanalysis and meta-synthesis study were found that bring all the available studies together and reports common shared findings. In this respect, the present research differs from other studies in the literature, and it is considered important since it will contribute to the field in terms of its results.

\subsection{Purpose}

Based on studies published in the literature, the study aimed to obtain a general view regarding the effects of mobile and IT supported education on preschool children's language development. In this context, the effects of mobile and IT supported education received by children aged 2-6 in the preschool education process on their language development were analyzed holistically using meta-analysis and meta-synthesis methods. The research question that would guide this research is:

RQ1: How does mobile and IT supported education affect the language development of preschool children?

\section{Method}

This study was designed using mixed - research method by employing qualitative and quantitative procedures together. Meta-analysis procedures were followed in the quantitative part of the study whereas meta-synthesis procedures were followed in the qualitative part of the study. Meta-analysis is the broad statistical analysis of the sum of the analysis results of individual studies in order to combine the findings of quantitative studies [Glass, 1976]. Meta-analysis is related to the analysis of analyses, combining, synthesizing and interpreting the experimental findings from individual studies. Meta-synthesis is a method developed to examine qualitative studies as a whole [Jensen \& Allen 1996]. Meta-synthesis is more interpretive than meta-analysis and tries to explain and understand the phenomena. This study is at the same time a Meta study since meta-research was carried out in both quantitative and qualitative dimensions. 
Meta studies follows a preferred systematic approach in the solution of sociological knowledge groups that are derived in different degrees in theory, method and data contexts [Paterson \& Canam, 2001].

\subsection{Selected studies for analyses}

Literature revealed various research about preschool education and the use of mobile and IT. Selection criteria for meta-analysis and meta-synthesis were determined. The criteria determined for the studies included in the meta-analysis are as follows; (1) experimental studies, (2) the studies reported effect size, (3) the studies sampled 2 to 6 aged children, (4) the studies reported the effect of mobile and IT on the language development and (5) the studies undertaken in the teaching environment. The criteria determined for the studies included in meta-synthesis are as follows; Qualitative studies (1) using any types of qualitative research patterns, (2) examining the effects of mobile and IT on any area covered by language development, (3) examining the views of preschool children aged 2-6, their parents and teachers. Considering all these criteria, 15 qualitative studies for meta-synthesis and 22 quantitative studies for meta-analysis were selected.

\subsection{Data collection}

After determining the criteria for the selection of the studies, the selection phase of this study was started. A series of steps were followed in the selection and assembly of the studies. Firstly, a team of four people who have conducted and experienced research on the subject was formed. This team first identified the keywords 'language development, mobile and IT', 'preschool language development' and 'literacy and mobile and IT' for studies to be included in meta-analysis and meta-synthesis. Then, databases to be scanned were determined, e.g., 'ResearchGate', 'Google Scholar', 'Science Direct', 'ERIC', 'Taylor \& Francis', 'EBSCO', 'Emerald', 'JSTOR', 'SAGE', YOK Thesis Center and 'SpringerLink'. It took approximately one month to review the databases. Many research on the subject were reached, but studies that did not satisfy the specified criteria were eliminated. Since all studies that complied with the determined criteria are included in the study, the study has the nature of being global and covering different cultures. Then, a coding form was prepared for the examination of research drawn from the databases. Each study was coded in terms of study identity (title, author, publication year, type of publication), study content (country, dependent - independent variables, etc.) and other data (qualitative - quantitative data).

\subsection{Data analysis: meta-analysis}

The analysis was carried out in two stages. Firstly, descriptive statistics of the studies included in the meta-analysis were made. Then, the meta-analysis process was initiated. Comprehensive Meta-Analysis V3 (CMA) package program was used to calculate the effect size. In studies where more than two methods were examined, the studies where ITs were applied most intensively were considered as the experimental group. Also, mean average, standard deviation, sample size, $\mathrm{p}, \mathrm{t}$ and $\mathrm{d}$ values given in the studies were used according to the multiple functions of the Comprehensive Meta-Analysis (CMA) program. After calculating the effect size of each study included in the meta- 
analysis, homogeneity test was also performed. Hedge's g statistic was calculated to determine the differences between the averages. Hedge's g shows how many standard deviations diverge from each other [Hedges and Olkin, 1985]. In the research, Statistical Package for the Social Sciences (SPSS) 21.0 program was used for coder reliability test. The significance level was determined as .05 for all statistical calculations in the study.

According to the results of the heterogeneity test of this research, the values showed a heterogeneous distribution. For this reason, the effect size was calculated by using the 'random effects model'. The effect size classification of Thalheimer and Cook (2002) was taken into consideration as; $-0.15<\mathrm{d}<0.15$ insignificant level, $0.15<\mathrm{d}<0.40$ low level, $0.40<\mathrm{d}<0.75$ medium level, $0.75<\mathrm{d}<1.10$ high level, $0.75<\mathrm{d}<1.10$ high level, $1.10<\mathrm{d}<1.45$ remarkably high level, and $1.45<$ d excellent.

\subsection{Reliability and validity of meta-analysis}

Funnel Plot, Orwin's Safe N test, Classic Safe N test and Egger test were used to determine the reliability and validity of the meta-analysis study and to reveal the bias of the publications. The Funnel plot of the effect sizes of the studies involving the effect of the use of IT on language development is shown in Figure 1.

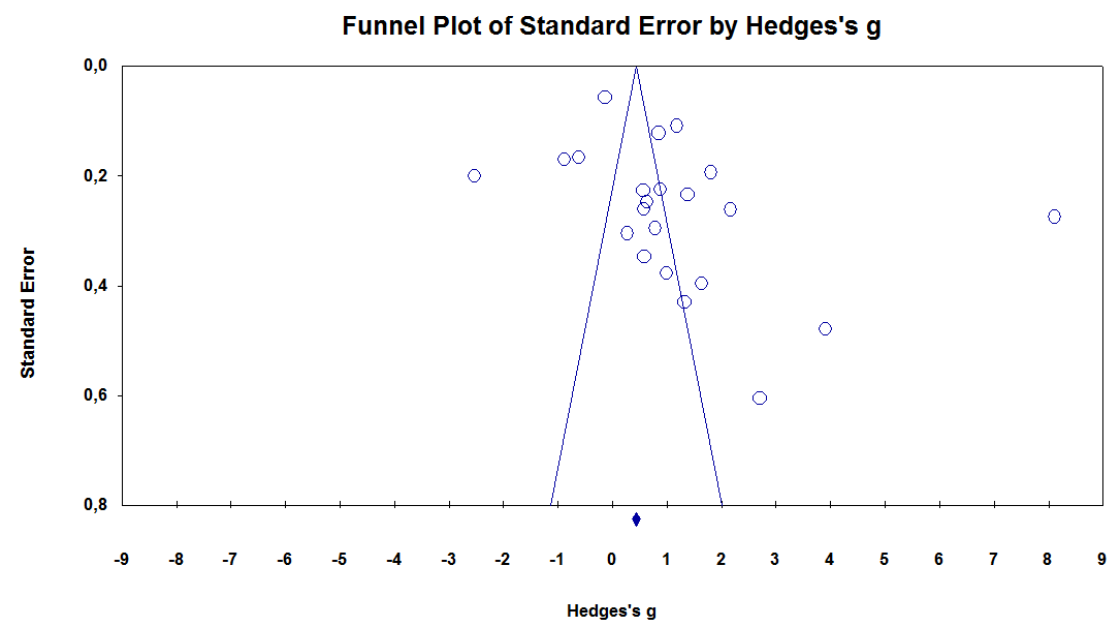

Figure 1: Funnel plot of effect sizes for studies involving the impact of IT

According to Figure 1, the effect size values are located at the top of the plot due to the large-scale range. Since the effect size of one of these studies is around 8 in Hedge's g, the scale is determined between -8 and 8 , and the standard error is between 0 and 0.8 . The plot also shows that there are Hedge's g values near to $-3,3$ and 4. For this scattered version of the graphic, it can be interpreted that the choice of publication was not biased. In addition, Egger test results, one of the bias indicators of funnel scatter plots, were evaluated [Egger: bias $=5.69(95 \%, \mathrm{CI}=-0.47$ to 11.85$), \mathrm{p}=0.03, \mathrm{p}<0.05$ ]. In the Egger test, which tests whether the funnel plot is asymmetrical or not, the $\mathrm{p}$ value is 
less than 0.05 . Thus, the funnel plot is not asymmetrical, and the study is far from bias. In addition, the results of Classical Safe $\mathrm{N}$ and Orwin error protection number were analyzed to determine the bias. Both test results support the results obtained from the Funnel plot. Classic Fail-Safe $\mathrm{N}$ test results are given in Table 1.

\begin{tabular}{ll}
\hline Classic Fail-Safe N & Values \\
\hline Z values for observed studies & 18,32 \\
$p$ values for observed studies & 0,00 \\
Alpha & 0,00 \\
Tail & 2,00 \\
Z values for alpha & 1,95 \\
Number of observed studies & 22,00 \\
fail-safe number [FSN] & 1902,00 \\
\hline
\end{tabular}

Table 1: Classical Fail-Safe $N$ test results

According to the Classical Fail-Safe $\mathrm{N}$ test, fail-safe number obtained from metaanalysis studies is 1902 . This result indicates that to eliminate the significance of the meta-analysis result, 1902 studies with an effect size of $p=0,000$ are required. The fact that this value is too high indicates that the study is far from high publication bias and highly heterogeneous. Orwin's Fail Safe N test results are given in Table 2. This test is to find out if there is publication bias.

\begin{tabular}{ll}
\hline Orwin's Fail Safe N & Value \\
\hline Hedge's g in observed studies & 0,43 \\
Criteria for trivial Hedge's & 0,00 \\
Mean of Hedge's g in missing studies & 0,00 \\
Number of studies required to decrease to the ineffective value & - \\
\hline
\end{tabular}

Table 2: Orwin's Fail Safe $N$ test results

Hedge's g was found to be 0.43 which is more than sufficient for heterogeneity. Thus, 'number of studies required to decrease to the ineffective value' [Sedliacik \& Dadob, 2017] could not be calculated. These results suggest that the study is heterogeneous and far from publication bias. 


\subsection{Data analysis: meta-synthesis}

During the meta-synthesis process, the meta-synthesis steps proposed by Creswell (1999) were followed as below.

- Readings over the selected articles are firstly made,

- The codes related to the research subject are determined,

- A common title regarding the codes is found and discussed by experts,

- Research findings are written within the framework of common themes.

Considering the above steps, 15 studies drawing from 112 studies which met the criteria were firstly examined one by one by a team of four experts. Later, each expert team member coded the findings part of the study independently and created themes. After that, team members came together and presented the codes and themes they identified to each other. These codes and themes were later discussed by team members, and common codes and themes were agreed upon.

\subsection{Reliability and validity of meta-synthesis}

Meta-synthesis is the work of interpreting, organizing and decomposing the findings of qualitative studies [Sandelowski et al., 1997]. In this context, thematic coding technique was used to reveal the findings. Similar to the meta-analysis done in the study, some precautions were taken into account for assuring the validity and reliability. For the selection of the qualitative studies, a set of criteria were determined and followed by the research experts in the team who searched the qualitative studies in the selected data bases. After that, the students were coded by the team members independently and later these codes were cross validated among the team members to reach the common codes and themes. Finally, list of common codes emerged from the analyzed studies were established which each team member agreed upon.

\section{Results}

\subsection{Meta-analysis results}

In Table 3, Most research were done in the Netherlands $(n=5)$. The studies done in Turkey $(n=3)$, Israel $(n=3)$ and the US $(n=3)$, and other countries were less. In Table 4 , the distribution of the studies by date is given.

The distribution of 22 experimental studies by country is given in Table 3 . 


\begin{tabular}{lll}
\hline Country & $F$ & $\%$ \\
\hline Germany & 1 & 4,54 \\
USA & 3 & 13,63 \\
Australia & 1 & 4,54 \\
Indonesia & 1 & 4,54 \\
South Taiwan & 1 & 4,54 \\
Nederland & 5 & 22,72 \\
Israel & 3 & 13,63 \\
Japan & 1 & 4,54 \\
Thailand & 2 & 9,09 \\
Turkey & 3 & 13,63 \\
Jordan & 1 & 4,54 \\
\hline Total & 22 & $\% 100$ \\
\hline
\end{tabular}

Table 3: Distribution of studies by country in meta-analysis

\begin{tabular}{lll}
\hline Year & $F$ & $\%$ \\
\hline 2002 & 1 & 4,54 \\
2004 & 1 & 4,54 \\
2006 & 1 & 4,54 \\
2008 & 1 & 4,54 \\
2009 & 2 & 9,09 \\
2010 & 2 & 9,09 \\
2013 & 2 & 9,09 \\
2014 & 3 & 13,63 \\
2015 & 2 & 9,09 \\
2016 & 2 & 9,09 \\
2017 & 2 & 9,09 \\
2018 & 2 & 9,09 \\
2019 & 1 & 4,54 \\
\hline
\end{tabular}

Table 4: Distribution of the studies by date in meta-analysis

The studies were carried out between the years 2002 and 2019. Most studies were conducted after 2014. The duration of intervention of the experimental studies are given in Table 5. 


\begin{tabular}{ccc}
\hline Duration & $F$ & $\%$ \\
\hline Not mentioned & 1 & 4,54 \\
9 days & 1 & 4,54 \\
2 weeks & 1 & \\
4 weeks & 2 & \\
5 weeks & 4,54 & 4,54 \\
6 weeks & 9,09 & 4,54 \\
8 weeks & 2 & 9,09 \\
9 weeks & 1 & 4,54 \\
2 months & 1 & 4,54 \\
3 months & 1 & 4,54 \\
4 months & 1 & 4,54 \\
1 semester & 4 & 18,18 \\
1 year & 3 & 13,63 \\
2 years & 2 & 9,09 \\
\hline
\end{tabular}

Table 5: Distribution of the studies by the duration of intervention

The intervention periods of the experimental studies were at least 9 days and at most 2 years.

In order to decide on the type of meta-analysis, it is first necessary to look at the heterogeneity of the studies. In the homogeneity test, there are information about both the fixed effects model and the random effects model. The findings of the fixed effects model are presented in Table 6 .

\begin{tabular}{|c|c|c|c|c|c|c|c|}
\hline \multirow{4}{*}{ Model } & \multirow{4}{*}{ Hedge's g } & \multirow{4}{*}{$\begin{array}{l}\text { Standard } \\
\text { Error }\end{array}$} & \multirow{4}{*}{ Variance } & $\% 95$ & Confidence & \multirow{4}{*}{$\mathbf{Z}$} & \multirow{4}{*}{$p$} \\
\hline & & & & \multicolumn{2}{|c|}{ Interval } & & \\
\hline & & & & Lower & Higher & & \\
\hline & & & & level & level & & \\
\hline \multicolumn{8}{|l|}{ Fixed } \\
\hline Effect & 0,43 & 0,03 & 0,00 & 0,35 & 0,50 & 11,83 & 0,00 \\
\hline Model & & & & & & & \\
\hline
\end{tabular}

Table 6: The findings of fixed effect model

$Z$ test was performed for statistical significance and found to be significant $[Z=11,83$, $\mathrm{p}=0,00, \mathrm{p}<0,05 ; \mathrm{SE}=0,03$; Variance $=0,00]$. The lower limit is 0.35 and the upper limit is 0.50 for the confidence interval of the effect size. Hedge's g was 0,43 . A 
positive value of Hedge's g indicates that the effect is in favor of the experimental group. This indicates that the use of IT in 2-6 age groups contributed positively to language development compared to other methods (control group).

The homogeneity test results decided whether the study would be interpreted according to the fixed effects or random effects model. Homogeneity test result was significant $[\mathrm{Q}=1463,08, \mathrm{I} 2=98,56, \mathrm{p}=0,00, \mathrm{p}<0,05]$. Since this value is much higher than the critical value, it is understood that the structure is heterogeneous. Also, since $\mathrm{p}$ value is less than 0.05 , there is a significant difference between the groups. Therefore, it can be concluded that the structure is heterogeneous. The I 2 test is a supplement to the $\mathrm{Q}$ test. The $\mathrm{Q}$ test is affected by the number of runs, while the $\mathrm{I} 2$ test is not affected by the number of runs. The I 2 value of $98 \%$ indicates that the study has a remarkably high level of heterogeneity.

As the structure is heterogeneous, the study was carried out with random effects model. In Table 7, the results of the random effects model are given.

\begin{tabular}{llllllll}
\hline Model & Hedge's g & $\begin{array}{l}\text { Standard } \\
\text { Error }\end{array}$ & Variance & $\begin{array}{l}\text { \%95 } \\
\text { Confidence } \\
\text { Interval }\end{array}$ & $\begin{array}{l}\text { Lower } \\
\text { level }\end{array}$ & $\begin{array}{l}\text { Higher } \\
\text { level }\end{array}$ & \\
\hline $\begin{array}{l}\text { Random } \\
\begin{array}{l}\text { Effect } \\
\text { Model }\end{array}\end{array}$ & 1,16 & 0,33 & 0,11 & 0,51 & 1,82 & 3,49 & 0,00 \\
\hline
\end{tabular}

Table 7: The findings of random effect model

Random effects model was statistically significant $[Z=3.49, p=0.00, p<0,05$; $\mathrm{SE}=0,33$; Variance $=0,11]$. The lower limit for the confidence interval of the effect size is 0.51 and the upper limit is 1.82 . Hedge's $g$ was 1,16 . Since this value is higher than 0.80 the effect size of the study is strongly high [Thalheimer \& Cook, 2002]. A positive value indicates that the effect is in favor of the experimental group. These results indicate that the use of IT in 2-6 years old groups has a strong and positive contribution to language development compared to other methods (control group).

The effect sizes and other statistical information reported in the studies examined on the effect of the use of IT on language development are summarized in Table 8. 


\begin{tabular}{|c|c|c|c|c|c|c|c|}
\hline Author & $\begin{array}{l}\text { Effect } \\
\text { Size }\end{array}$ & $\begin{array}{l}\text { Standard } \\
\text { Error }\end{array}$ & Variance & $\begin{array}{l}\text { Lower } \\
\text { Limit }\end{array}$ & $\begin{array}{l}\text { Higher } \\
\text { Limit }\end{array}$ & $\mathbf{Z}$ & $p$ \\
\hline $\begin{array}{l}\text { Nir-Gal and Klein } \\
(2004)\end{array}$ & 1,81 & 0,19 & 3,73 & 1,43 & 2,18 & 9,36 & 0,00 \\
\hline Altun (2019) & 1,17 & 0,10 & 1,17 & 0,96 & 1,38 & 10,85 & 0,00 \\
\hline Masataka (2014) & 0,57 & 0,26 & 6,77 & 6,56 & 1,08 & 2,21 & 0,02 \\
\hline Blankson et al. (2015) & 8,11 & 0,27 & 7,52 & 7,57 & 8,65 & 29,58 & 0,00 \\
\hline Lin et al. (2015) & $-0,61$ & 0,16 & 2,76 & $-0,94$ & $-0,29$ & $-3,71$ & 0,00 \\
\hline $\begin{array}{l}\text { Özyurt and Eliküçük } \\
\text { (2017) }\end{array}$ & $-2,53$ & 0,19 & 3,98 & $-2,92$ & $-2,14$ & $\begin{array}{l}- \\
12,69\end{array}$ & 0,00 \\
\hline Cubelic (2013) & 0,84 & 0,12 & 1,49 & 0,60 & 1,08 & 6,94 & 0,00 \\
\hline $\begin{array}{l}\text { Varhallen and Bus } \\
\text { (2010) }\end{array}$ & 0,56 & 0,22 & 5,12 & 0,12 & 1,00 & 2,49 & 0,01 \\
\hline $\begin{array}{l}\text { Walter-Laager et al. } \\
\text { (2016) }\end{array}$ & 0,58 & 0,34 & 0,12 & $-9,61$ & 1,26 & 1,68 & 0,09 \\
\hline $\begin{array}{l}\text { Kozminsky and } \\
\text { Asher-Sadon (2013) }\end{array}$ & 3,90 & 0,47 & 0,23 & 2,96 & 4,84 & 8,14 & 0,00 \\
\hline Jong and Bus (2002) & 1,64 & 0,39 & 0,15 & 0,86 & 2,41 & 4,14 & 0,00 \\
\hline Korat (2010) & 1,38 & 0,23 & 5,48 & 0,92 & 1,83 & 5,89 & 0,00 \\
\hline Maureen et al. (2018) & 1,32 & 0,43 & 0,18 & 0,48 & 2,16 & 3,08 & 0,00 \\
\hline Choosri et al. (2017) & 0,99 & 0,37 & 0,14 & 0,25 & 1,73 & 2,62 & 0,00 \\
\hline Teepe et al. (2016) & 0,63 & 0,24 & 0,06 & 0,15 & 1,12 & 2,58 & 0,01 \\
\hline Chonchaiya (2008) & $-0,87$ & 0,17 & 2,90 & $-1,20$ & $-0,54$ & $-5,13$ & 0,00 \\
\hline Yüksel et al. (2014) & 0,88 & 0,22 & 0,05 & 0,44 & 1,32 & 3,93 & 0,00 \\
\hline Ihmeideh (2014) & 2,16 & 0,26 & 6,82 & 1,65 & 2,67 & 8,27 & 0,00 \\
\hline Varhallen et al. (2006) & 2,70 & 0,60 & 0,36 & 1,51 & 3,89 & 4,46 & 0,00 \\
\hline Neumann (2018) & 0,78 & 0,29 & 8,70 & 0,20 & 1,36 & 2,66 & 0,00 \\
\hline $\begin{array}{l}\text { Linebarger and } \\
\text { Piotrowski (2009) }\end{array}$ & $-0,13$ & 0,05 & 3,22 & $-0,24$ & $-2,31$ & $-2,36$ & 0,01 \\
\hline $\begin{array}{l}\text { Varhallen and Bus } \\
\text { (2009) }\end{array}$ & 0,27 & 0,30 & 9,27 & $-0,32$ & 0,87 & 0,90 & 0,36 \\
\hline
\end{tabular}

Table 8: The effect sizes and other statistical information reported in the studies

The effect sizes reported in the studies ranged from -2.53 to 8.11 . While 21 of the interventions were statistically significant, only one was not significant $(\mathrm{p}>0.05)$. The effect size was positive in 18 studies and negative in 4 studies. These results signifies that the effect of mobile and IT on language development was in favor of the 
experimental group in 18 studies, whereas in 4 studies, the practices in the control group had more effect on language development.

In addition, in order to understand the levels of effect sizes, a forest plot was created. Forest graph showing the effect of language development in experimental and control groups is given in Figure 2.

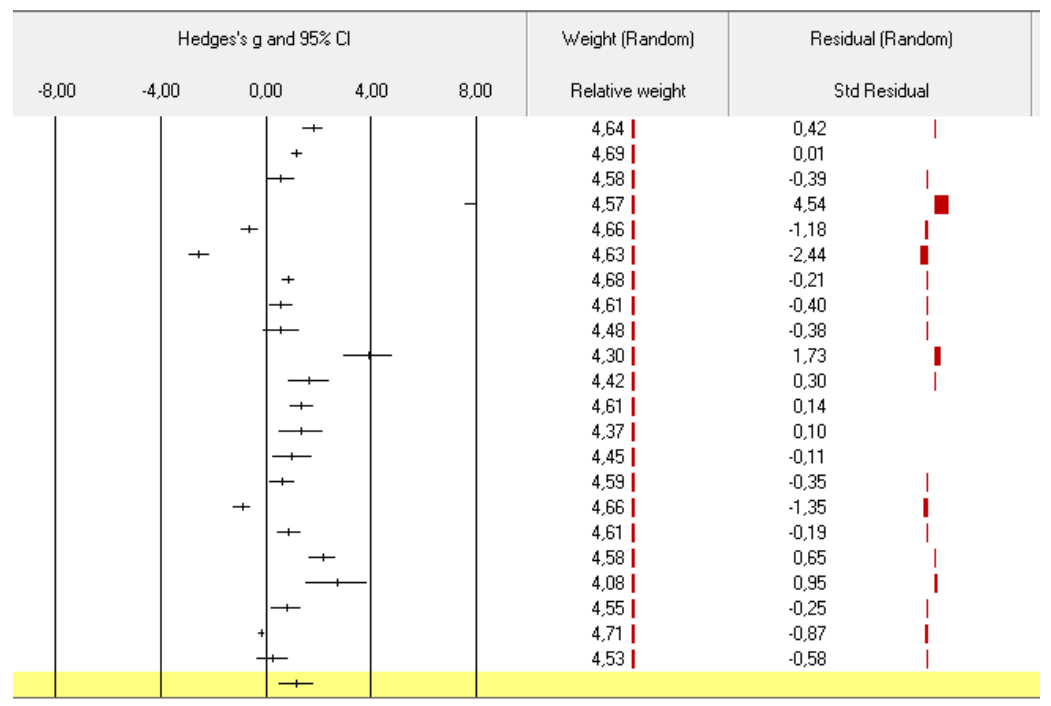

Figure 2: Forest graphic and weights of the studies

Based on $[-8,+8]$ range, the figure shows that four students were in favor of control group and the remaining studies were in favor of experimental groups. Random effect was above 0,00 . Therefore, considering the general effect size obtained in the metaanalysis, the effect size is high and in favor of the experimental group.

\subsection{Meta-synthesis results}

The distribution of 15 qualitative studies by country is given in Table 9 .

\begin{tabular}{lll}
\hline Country & $F$ & $\%$ \\
\hline USA & 5 & 33,33 \\
England & 2 & 13,33 \\
Cyprus & 1 & 6,66 \\
Kosovo & 1 & 6,66 \\
Norway & 1 & 6,66 \\
Turkey & 3 & 20,00 \\
New Zeeland & 1 & 6,66 \\
Greece & 1 & 6,66 \\
\hline
\end{tabular}

Table 9: Distribution of studies by country in meta-synthesis 
In Table 9, most research were conducted in USA $(n=5)$. The research done in Turkey $(n=3)$, the UK $(n=2)$, and other countries are less. Table 10 shows the distribution of the studies by years.

\begin{tabular}{lll}
\hline Year & $F$ & $\%$ \\
\hline 2001 & 2 & 13,33 \\
2008 & 1 & 6,66 \\
2010 & 1 & 6,66 \\
2012 & 1 & 6,66 \\
2013 & 1 & 6,66 \\
2014 & 1 & 6,66 \\
2015 & 2 & 13,66 \\
2016 & 1 & 6,66 \\
2017 & 1 & 6,66 \\
2018 & 1 & 6,66 \\
2019 & 3 & 20 \\
\hline
\end{tabular}

Table 10: Distribution of the studies by years in meta-synthesis

The selected studies in meta-synthesis were undertaken between 2001 and 2019. Most studies were performed in 2019. Meta-analysis of 15 qualitative studies emerged a total of 117 codes grouped under six themes as 1) Purposes of mobile and IT usage, (2) mobile and IT experiences of teachers and parents, (3) technological readiness of kindergartens, (4) positive opinions, (5) negative opinions, (6) inferences and recommendations.

\subsection{Theme 1: purposes of Mobile and IT usage}

There are nine codes in this theme. Teachers preferred to use mobile and IT in music activities and language activities in the classroom [Kirliauskiene \& Abramauskiené, 2020]. According to a study conducted in Turkey, teachers used mobile and IT for listening to children's songs. This enabled children to listen fairy tale storytelling, watch prepared presentations and cartoons.

Children interact with mobile phones, tablets, computers and television devices among other mobile and IT tools [Al-Johali, 2019]. Children often use mobile and IT tools to watch animated movies and play digital games. In addition, children watch digital images (photos, videos, animations) shared between family and friends via mobile and IT tools.

Games and entertainment are the primary goals of children to use mobile and IT. Furthermore, parents reported that their children used mobile and information 
technologies for educational and artistic purposes. Some families use mobile and IT tools (especially tablets and phones) to control their children, to calm them and to relieve their troubles.

\subsection{Theme 2: IT experiences of teachers and parents}

There are 15 codes in this theme. Teachers' and parents' technological literacy levels varied in the selected studies. Some of the teachers and parents said they have a "know how" use of mobile and IT, while others to have "advanced knowledge". Teachers with inadequate technology literacy used limited or no use of mobile and IT tools in classrooms.

A large number of teachers traditionally trained had insufficient experience in using mobile and IT, while others did not have sufficient knowledge and experience in using mobile and IT in preschool level. Lack of knowledge and experience can affect teachers' beliefs, attitudes, and practices in their current work with young children. Most of the parents with lack of technology literacy used TV (programs) for educational purposes, but they did not consider their children's developmental appropriateness.

\subsection{Theme 3: technological readiness of kindergartens}

There are nine codes in this theme. Technological readiness of kindergartens varies from country to country and within countries, from region to region. Most common IT tool was TV and teachers tended to use TV for educational purposes and to calm the children. In one study, five out of eight kindergartens rarely used video projectors and teachers thought it was logistically objectionable to organize projector use. In one study, class was designed with limited number of computers and the teacher used the computer to improve children's interactions and conversations. In this way, children are encouraged to work together and share their projects. With computers where software and drawing programs are installed, children are encouraged to explore in depth.

\subsection{Theme 4: positive opinions}

There are 52 codes in this theme. The participants (teacher, parents, and children) in the studies indicated mainly that use of IT influenced on the language development of preschool children in a positive way. Some children had a lot of self-speech when playing with apps, labelling items on the screen, imitating the language they heard, repeating the words or phrases read to them. The use of mobile and IT tools contributed to language development-related areas such as vocabulary learning, concept learning, using language well, developing communication skills, speeding up language development, pronouncing words correctly, eliminating speech impairment, expressing yourself, using courtesy words, developing imagination. Parents stated that the development of their children increased in many areas of development, e.g., language development, cognitive, early learning skills and technology skills. In addition, mobile and IT was also used for foreign language acquisition. 


\subsection{Theme 5: negative opinions}

There are 11 codes in this theme. Lack of socialization, modelling negative behavior, risk of addiction, eye health problems, lack of movement, negatively affecting mental development and delaying language development were seen to be among the negative effects of mobile and IT based educational devices. Some parents believed that the use of mobile and IT caused problems such as child introversion, living an isolated life and exposure to radiation.

\subsection{Theme 6: inferences and recommendations}

There are 21 codes in this theme. There are two contradictory thoughts (progressive and regressive philosophies) among parents' and preschool teachers' perceptions and practices regarding the use of digital technologies in the learning and development of young children. While one side thought that mobile and IT supported language development, the other side thought that it caused decline in the language development. It is believed that the reason for such an idea is to be uncontrollable. The need for proximal and distal guided interaction to improve children's learning with mobile and IT indicated the provision of direct interaction and indirect planning.

Preschool teachers used technology in their classrooms to increase their students' language awareness; however, teachers were usually advised to be careful when using technology in and out of the classroom or eliminating the negative effects of mobile and IT usage. In addition, it is recommended that teachers create task-based activities and prepare project work for their students. It is the common view of the studies that software programs should be carefully selected and standardized by considering the developmental stages of the children and used accordingly.

\section{Discussion}

\subsection{Meta-analysis}

The meta-analysis done in the study showed that the study was heterogeneous, and the effect size was remarkably high (Hedge's $g=1.16$ ). This result indicates that supportive and educational practices carried out using IT in preschool age have a high level of positive effect on children's language development. Research results in the literature are in line with this result.

Grgurović et al. (2013) conducted a meta-analysis of experimental research investigating language outcomes in order to examine the effect of second foreign language teaching supported by computer technology. They analyzed 52 effect sizes obtained from 37 studies conducted between 1970 and 2006. They found that the common effect value was positive and small, and computer-assisted foreign language pedagogy was more effective.

In a meta-analysis study where the effects of mobile devices on students' learning performances were investigated, the effect size of mobile technology applications to improve their communication and collaboration skills was found to be remarkably high [Sung et al., 2016]. Review of literature revealed limited number of meta-analysis studies about the study. The available ones [Qassem, 2020] produced similar results to 
the present study such that the use of IT in the language development of preschool children is significant.

\subsection{Meta-synthesis}

Teachers used mobile and IT to support the language development of children, especially for singing and playing. In classroom activities, teachers mostly use technological devices while playing games, teaching songs, watching educational cartoons or telling stories [Şalc1 et al., 2018]. In addition to having fun while teaching children with IT technologies, students at the same time, learned the topic covered. Aral and Keskin (2018) emphasized that children mostly used technological devices to watch animated movies and play games. Similar results were obtained in the surveys conducted with parents. Mothers used tablets for their children and allowed children to watch animations or play games to calm the children in the home environment and get their own work done easily [Billington \& Trust, 2016]. There are also studies in which children were encouraged to examine photos and videos in IPad, and then they were asked to make comments on them [Hatherly \& Chapman, 2012]. Hatherly and Chapman (2012) claimed that children's interpretation skills improved as well as their language development. The results of this research and other studies in the literature are in line with one other study which concluded that mobile and IT is used in preschool education for many purposes and contribute to language development [Gruber \& Bailey, 2021].

Teachers with more teaching experience have fewer positive attitudes towards technology and tend to use less technology than those with less teaching experience [Blackwell et al., 2014]. This implies that teachers trained with today's education are more sensitive to education with technology. To keep up with the technological advances and be aware of the impact of mobile and IT, parents and teachers should be guided in technology education [Plowman et al., 2010].

Lack of use for authentic activities and limitations on mobile and IT available in most preschool settings let teachers have fewer opportunities for children to develop language skills. Preschool school staff have limited knowledge of children's home experiences in technology. Therefore, parents, school administration and teachers should cooperate and support the advancement of technology and development areas of children.

In some observations done over preschool children, guided interaction practice showed that language was not dominant as a mere form of communication, as it is an example of extended adult-child dialogue [Plowman \& Stephen, 2007]. Speech is an important tool for interaction in classrooms, but emotional responses are at the core of the practitioner's role in preschool settings. Therefore, touch, gesture and eye contact are also important forms of communication.

Today, it is inevitable to use digital technologies in education system [Mendez, Mendez \& Anguita, 2020]. Different stakeholders in language development should recognize the benefits and risks that technology brings to children and teachers. Collaboration should be ongoing among parents and teachers to ensure their hopes of maximizing collaboration and mitigating potential risks in early childhood education [Diana, Sunardi, Gunarhadi \& Munawir, 2020]. A meta-synthesis revealed that parents and teachers generally support technology-aided education, but they thought that this type of practice should not be overused. 
Technological infrastructures of the preschools in different countries and school types were varied. This may cause to equality of opportunity in terms of reaching IT in educational settings. According to Olowe and Kutelu (2014), in early childhood education, mobile and IT includes more than digital cameras, creativity and communication software and tools, internet, phones, mobile phones, tapes, interactive stories, computer games, programmable toys, video conferencing technologies and closed-circuit television, data projectors, microphones, headset electronic whiteboards [Tavasoli, Mowlaie, Majid \& Rahimi, 2020]. However, even in developed countries of the world, many of these technologies cannot be provided in classroom settings in many schools. Especially private schools are far ahead of public schools in terms of IT infrastructure.

When mobile and IT is integrated with the educational process, better language development such as letters recognition, sorting and sounds awareness, literacy, listening and understanding of words and stories can be developed [Primavera et al., 2001; Nir-Gal \& Klein 2004; Penuel et al., 2009]. For example, children with daily access to a large library of educational software and to teacher supervision achieved more, but children who attend weekly sessions with a counsellor who facilitates the use of technology achieved even more [Primavera et al., 2001]. When researchers used interactive smart boards (IWB), they observed more collaboration among preschool children than when they used traditional desktop computers (with non-touch screen, mouse and keyboard).

In their study, Gjelaj et al. (2020) found that parents had positive attitudes towards the use of digital technologies in early childhood education. In addition, the parents expressed their thoughts in favor of technology in the development of their children and supported the process of exposing their children to technology resources. Thus, teacher and parents supported the use of mobile and IT in preschools for language development.

The types of technological tools used by young children and their duration of use have recently increased. In a study conducted in the USA (Common Sense Media, 2013), it was observed that the proportion of children with smartphones, tablets, iPod touch and similar devices and any mobile devices increased by $6-32 \%$ between the ages of 0 and 8. In another study conducted on children aged between 15-35 months in South Taiwan, a relationship was found between television viewing time and linguistic, cognitive and motor delay. Parallel to the available studies, the current study indicated that excessive dependence on technological devices was parents' main concern.

Increase in aggression, negative impact on empathic views to others, damage in inter-personal skills and language problems are stated as the negative effects of technological devices [Armstrong \& Casement, 2000; Markman, 2010; Saleem et al., 2012]. It may be assumed that the duration of watching television, portable computers and using some other devices on weekdays may affect peer relationships negatively.

\section{Conclusion}

\subsection{Suggestions for practitioners}

Professionals should consider appropriate but proactive pedagogical approaches that can be developed for young children to learn and play with digital media. Teachers need to receive important support and to have experience in the use of digital media. 
For this reason, it may be suggested to rearrange the information technologies course contents in preschool teacher undergraduate programs in this context. Preschool teachers should be encouraged to participate in in-service trainings that demonstrate the use of mobile and IT and its impact on language development. Also, necessary infrastructure must be provided for using mobile and IT in classrooms. Mobile and IT supported practices (e.g., robotic coding) for language development should be designed as a result of joint opinions and studies of technologists, preschool education and child development specialists, considering children's development. Proximal and distal guided interaction is needed to improve children's learning with mobile and IT. It is necessary to arrange trainings for adults to use mobile and IT by direct interaction and indirect planning, and to teach correct information about how to support children's language and other development in these trainings.

\subsection{Suggestions for further research}

Increasing the number of studies on the use of mobile and IT in preschool language development is necessary to create a general view on this subject. In future research, mobile and IT practices in different countries and school type should be examined for the comparison. Also, the effects of education enriched with mobile and IT, drama and game on language development should be designed.

\section{Acknowledgements}

This study is based on the Ph.D. thesis titled "The effect of mobile and information technologies (IT) supported education on the language development of preschool children: a meta-analysis and meta-synthesis study".

\section{References}

[Acar and Dogan, 2007] Acar, A. Ö., \& Doğan, N.: Okulöncesi Eğitimde Bilgisayar Destekli Eğitimin Rolü, Akademik Bilişim Confrence, 31 Ocak-2 Şubat, 2007. https://ab.org.tr/ab07/bildiri/43.pdf

[Aitchison, 2018] Aitchison, E.: How the use of technology can be integrated into early childhood education, with an emphasis on children aged 3-5 years old, (Unpublished Bachelor's Thesis), Laurea University, 2018. http://urn.fi/URN:NBN:fi:amk-201803293969

[Al-Johali, 2019] Al-Johali, K. Y.: Using mobile applications to teach vocabulary: Saudi EFL teachers' perceptions. Global Journal of Foreign Language Teaching, 9(1), 51-68, February 2019. https://tinyurl.com/yz8yrsxq

[Altun, 2019] Altun, D.: Investigation of the receiver and expressive language knowledge of 6071-month preschool children in accordance with technology use and family factors. International Journal of Turkish Literature Culture Education (TEKE), 8 (2), 1158-1182, 2019. https://dergipark.org.tr/en/pub/teke/issue/46075/580146

[Aygün et al., 2016] Aygün, Ş. S., Atalay, N., Kiliç, Z., \& Yaşar, S.: Developing 21st century skills competence perceptions scale for prospective teachers: a validity and reliability study. Pamukkale University Journal of Education, 40 (40), 160-175,2016. https://dergipark.org.tr/en/pub/pauefd/issue/33883/375190 
[Aral, 2006] Aral, N.: Anaokuluna devam eden altı yas grubundaki çocukların kavram gelişiminde bilgisayar destekli öğretmen etkisinin incelenmesi, Ankara University Scientific Research Project Final Report. 2006. http://hdl.handle.net/20.500.12575/68242

[Armstrong and Casement ,00] Armstrong, A., \& Casement, C. :). The child and the machine: How computers put our children's education at risk. Beltsville, MD: Robins Lane Press, 2000. https://tinyurl.com/yzq4c2rj

[Arnas, 2005] Arnas, Y.: Okul öncesinde bilgisayar destekli eğitim. Eurasian Journal of Educational Research, 20, 36-47, 2005. https://app.trdizin.gov.tr/publication/paper/detail/TIRBeE56RXg=

[Billington and Trust, 2016] Billington, C., \& Trust, N. L.: How digital technology can support early language and literacy outcomes in early years settings: A review of the literature. National Literacy Trust. 1-17, 2016. https://tinyurl.com/yhk6dttq

[Blackwell et al., 2014] Blackwell, C. K., Lauricella, A. R., \& Wartella, E.: Factors influencing digital technology use in early childhood education. Computers \& Education Journal, 77, 82- 90, 2014. https://doi.org/10.1016/j.compedu.2014.04.013

[Blankson, 2015] Blankson, A. N., O’Brien, M., Leerkes, E.M., Calkins, S.D., \& Marcovitch, S.: Do hours spent watching television at age 3 and 4 predict vocabulary and executive functioning at age 5? Merrill Palmer Quarterly, 61, 264-289, 2015. https://doi.org/10.13110/merrpalmquar1982.61.2.0264

[Blumet al., 2009] Blum, C., Parette, H. P., \& Watts, E. H.: Engaging young children in an emergent literacy curriculum using of Microsoft_PowerPoint: Development, considerations, and opportunities. In A. M. Vilas, A. S. Martin, J. M. Gonza'lez, \& J. A. Gonza'lez (Eds.), Research, reflections and innovations in integrating ICT in education (Vol. 1, pp. 41-45). Badajoz, Spain: Formatex, 2009. https://tinyurl.com/yzexg8g4

[Boe, 2013] Boe, C. S.: Have 21st century skills made their way to the university classroom? a study to examine the extent to which 21 st century skills are being incorporated into the academic programs at a small, private, Church-Related University (Unpublished Doctoral dissertation). Gardner-Webb University, 2013. https://digitalcommons.gardner-webb.edu/education_etd/29/

[Bus et al., 1995] Bus, A. G., Van Ijzendoorn, M. H., \& Pellegrini, A. D.: Joint book reading makes for success in learning to read: A meta-analysis on intergenerational transmission of literacy. Review of educational research, 65(1), 1-21, 1995. https://doi.org/10.3102\%2F00346543065001001

[Casper and Theilheimer, 2010] Casper, V., \& Theilheimer, R.: Early childhood education, New York: McGraw Hill, 2010.

[Cavus, 2020] Cavus, N.: Evaluation of MoblrN m-learning system: Participants' attitudes and opinions. World Journal on Educational Technology: Current Issues, 12(3), 150-164, 2020. https://eric.ed.gov/?id=EJ1267178

[Ceker and Uzunboylu, 2017] Ceker, E. \& Uzunboylu, H.: A Dilemma on "Web-based/Mobile Assessment" by or for Teachers: A Content Analysis. Journal of Universal Computer Science. 23(12), 1238 2017. http://jucs.org/jucs_23_12/a_dilemma_on_webbased/jucs_23_12_1238_1255_ceker.pdf

[Celik, and Uzunboylu, 2020] Celik, B. \& Uzunboylu, H.: Developing an attitude scale towards distance learning, Behaviour \& Information Technology, 2020. https://doi.org/10.1080/0144929X.2020.1832576 
[Chamot and Keatley, 2004] Chamot, A.U. \& Keatley, C.W.: Learning strategies of students of less commonly taught languages. Paper presented at the 2004 Annual Meeting of the American Educational Research Association, San Diego, CA, 2004.

[Chonchaiya and Pruksanonda, 2008] Chonchaiya, W. \& Pruksananonda, C.: Television viewing associates with delayed language development. Journal Compilation/Foundation Acta Pædiatrica/Acta Pædiatrica. 97, 977-982, 2008. https://doi.org/10.1111/j.16512227.2008.00831.x

[Choosri et al., 2017] Choosri, N., Chompoonut, P., Swangtrakul, N. \& Atkins, A.: Tangible interface game for stimulating child language cognitıve skill. IADIS International Journal. 2, 17 31, 2017. https://tinyurl.com/yzh2kgs7

[Common Sense Media, 2013] Common Sense Media.; Zero to eight children's media use in America 2013. Access: https://www.commonsensemedia.org/research

[Creswell, 1999] Creswell, J. W.: Mixed-method research: Introduction and application. In G. J. Cizek (Ed.), Handbook of educational policy. (pp. 455-472). New York: Academic Press, 1999. https://doi.org/10.1016/B978-012174698-8/50045-X

[Cubelic, 2013] Cubelic, C. J.: Ipad 2 applications and emergent literacy: do they have an 1mpact on the acquistion of early literacy skills? (Unpublished doctoral thesis). Youngstown State Unıversity, 2013.http://rave.ohiolink.edu/etdc/view?acc_num=ysu1370348007

[Dağyar, 2020] Dağyar, M., Kasalak, G., \& Sezgin, E.: What do primary school students think about mobile programming education? 'Developing my own mobile game'. World Journal on Educational Technology: Current Issues, 12(4), 258-277. https://doi.org/10.18844/wjet.v12i4.5179

[Demo et al., 2012] Demo, G. B., Moro, M., Pina, A., \& Arlegui, J.: In and out of the school activities implementing IBSE and constructionist learning methodologies by means of robotics. In B. S. Baker, G. Nugent, N. Grandgennet, \& V. I. Adamchuk (Eds.), Robots in K-12 education: A new technology for learning (pp. 66-92). IGI Global, 2012. https://www.igiglobal.com/chapter/content/63410

[Diana et al, 2020] Diana, D., Sunardi, S., Gunarhadi, G., \& Munawir, Y.: The development of I-Teach model to improve early childhood teachers professionalism. Cypriot Journal of Educational Sciences, 15(6), 1614-1628, 2020. https://doi.org/10.18844/cjes.v15i6.5321

[Dörnyei, 2001] Dörnyei, Z.: Motivational strategies in the language classroom. NY: Cambridge University Press, 2001. https://doi.org/10.1017/S0267190501000034

[Elgharnah and Ozdamli, 2020] Elgharnah, K. G. E., \& Ozdamli, F.: Determining parents' level of awareness about safe internet use. World Journal on Educational Technology: Current Issues, 12(4), 290-300, 2020. https://doi.org/10.18844/wjet.v12i4.5182

[Elsayed and Salama, 2020] Elsayed, M., \& Salama, R.: Educational games for missconcentration students (ADHD students). International Journal of Innovative Research in Education, 7(1), 26-31, 2020. https://doi.org/10.18844/ijire.v7i1.4762

[Gardner, 1985] Gardner, R.C.: Social psychological aspects of language learning: The role of attitudes and motivation. London: Edward Arnold, 1985. https://publish.uwo.ca/ gardner/docs/SECONDLANGUAGE1985book.pdf

[Gjelaj, 2020] Gjelaj, M., Buza, K., Shatri, K., \& Zabeli, N.: Digital technologies in early childhood: attitudes and practices of parents and teachers in Kosovo. International Journal of Instruction, 13(1), 165-184, 2020. http://www.e-iji.net/dosyalar/iji_2020_1_11.pdf 
[Glass, 1976] Glass, G. V.: Primary, secondary and meta-analysis of research. American $\begin{array}{llllll}\text { Educational } & \text { Research } & \text { Association, } & 5 & \text { (10), } & 3-8,\end{array}$ https://doi.org/10.3102\%2F0013189X005010003

[Goh and Ali, 2014] Goh, H., \& Ali, M. B. B.: Robotics as a tool to Stem Learning, International Journal for Innovation Education and Research, 2(10), 66-78, 2014. https://pdfs.semanticscholar.org/68cb/ee2743984093a24109a6e577a3ed7c00ad88.pdf

[Greenhill, 2010] Greenhill, V.: 21st Century knowledge and skills in educator preparation, $\begin{array}{llll}\text { Partnership for } & 21 \mathrm{st} & \text { century } & \end{array}$ https://tfsfusa.org/files/Docs/TE/AACT\%20Whitepaper.pdf

[Grgurović et al., 2013] Grgurović, M., Chapelle, C. A., \& Shelley, M. C.; A meta-analysis of effectiveness studies on computer technology-supported language learning. European Association for Computer Assisted Language Learning. 25(2), 165-198, 2013. http://dx.doi.org/10.1017/S0958344013000013\%20

[Gruber et al., 2021] Gruber, A., \& Bailey, A. C.: Examining EFL students' pluricultural and plurilingual development during intercultural virtual exchanges between Colombia and Germany. Global Journal of Foreign Language Teaching, 11(1), 14-29, 2021. https://doi.org/10.18844/gjflt.v11i1.5148

[Gülmez, 2019] Gülmez, E.: Using youtube as an educational technology in preschool concept teaching (Master's thesis, Necmettin Erbakan University Institute of Educational Sciences),2019. https://hdl.handle.net/20.500.12452/6725

[Gündoğan, 2014] Gündoğan, A.: Okul öncesi dönemde bilgisayar destekli eğitim projeleri, Gazi Üniversitesi Gazi Eğitim Fakültesi Dergisi GEFAD / GUJGEF, 34(3), 437-449, 2014. http://www.gefad.gazi.edu.tr/en/download/article-file/77516

[Günüç, 2018] Günüç, S., \& Atli, S.: Parents' views on the impact of technology on babies aged 18-24 months. Addicta: The Turkish Journal on Addictions, 5 (2), 1-22, 2018. https://www.addicta.com.tr/Content/files/sayilar/17/6TR.pdf

[Hatherly, 2013] Hatherly, A., \& Chapman, B.: Fostering motivation for literacy in early childhood education using iPads. Computers in New Zealand Schools: Learning, teaching, technology, 25(1-3), 138-151, 2013. https://www.otago.ac.nz/cdelt/otago065362.pdf

[Hedges, 1985] Hedges L. V., Olkin I.: Statistical methods for meta-analysis. San Diego, CA: Academic Press, 1985. https://doi.org/10.1016/C2009-0-03396-0

[Howard, 1991] Howard, J. R. \& Busch, J.: The change-over to computer-based tecnology in early childhood special education, Journal of Research on Computing in Education, 23(4);530565, 1991. https://doi.org/10.1080/08886504.1991.10781980

[Hussein, 2019] Hussein, N., \& Albakri, I.: The role of strategies on developing Iraqi learners' usage of request in EFL classroom. International Journal of English, Literature and Social Science, 4(5), 1337-1341, 2019. https://tinyurl.com/yfjjc3zm

[Ihmeideh, 2017] Ihmeideh, F. M. \& Alkhawaldeh, M. F.: Teachers' and parents' perceptions of the role of technology and digital media in developing child culture in the early years. Children $\begin{array}{lllll}\text { and Youth } & \text { Services } & \text { Review, }\end{array}$ https://doi.org/10.1016/j.childyouth.2017.04.013

[İnci, 2017] İnci, M. A., \& Kandır, A.: Evaluation of scientific studies related to the use of digital technology in preschool education, Hitit University Journal of Social Sciences Institute, Year 10, 2, 1705-1724, 2017. https://www.ceeol.com/search/article-detail?id=640872 
[Isik, 2019] Isik, B., \& Jallad, S. T.: The potential of social media and nursing education: Eprofessionalism, nurse educator-learner role, benefits and risks. New Trends and Issues Proceedings on Advances in Pure and Applied Sciences, (11), 30-38, 2019. https://doi.org/10.18844/gjpaas.v0i11.4310

[Jensen, 1994] Jensen, L., \& Allen, M.: A synthesis of qualitative research on wellness-illness. $\begin{array}{lllll}\text { Qualitative Health } & \text { Research. }\end{array}$ https://doi.org/10.1177\%2F104973239400400402

[Jong, 2002] Jong, M. T. \& Bus, A. G.: Quality of book-reading matters for emergent readers: an experiment with the same book in a regular or electronic Format. Journal of Educational Psychology, 94 (1), 145-155, 2002. https://psycnet.apa.org/doi/10.1037/0022-0663.94.1.145

[Kandir, 2008] Kandir, A., \& Alpan, UY: The effect of parents' behaviors on social-emotional development in preschool period. Journal of Social Policy Studies, 14(14), 33-38, 2008.

[Karabulutlu, 2018] Karabulutlu, L.: Analogies in preschool science education and evaluation of computer-aided education in terms of academic success (Unpublished master thesis). Kafkas University, 2018.

[Karakaya et al., 2017] Karakaya, S., Akkaya, U., Sekerci, N., Karagoz, A., Ozay, A. U., Kucukyildiz, G., \& Ocak, H.: Virtual-reality-based remote-controlled mobile robot platform. Global Journal of Computer Sciences: Theory and Research, 7(3), 136-144, 2017. https://doi.org/10.18844/gjcs.v7i3.2799

[Keser 2019] Keser, H., \& Semerci, A.: Technology trends, Education 4.0 and beyond.

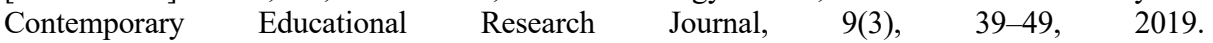
https://doi.org/10.18844/cerj.v9i3.4269

[King, 1971] King, R., Raynes, N. \& Tizard, J.: Patterns of residential care: sociological studies in institutions for handicapped children. London: Routledge \& Kegan Paul, 1971. https://www.cabdirect.org/cabdirect/abstract/19722702416

[Kiracioglu et al., 2019] Kiracioglu, D., Demirbas-Celik, N., \& Aytaç, P.: Effectiveness of family involvement activities in preschool education. Global Journal of Guidance and Counseling in Schools: Current Perspectives, 9(3), 131-137, 2019. https://doi.org/10.18844/gjgc.v9i3.4489

[Kirliauskienè, 2020] Kirliauskienè, R., \& Abramauskienè, J.: Intuition in music education. Global Journal of Arts Education, 10(2), 157-166, 2020. https://doi.org/10.18844/gjae.v10i2.4734

[Kocaman-Karoğlu, 2016] Kocaman-Karoğlu, A.: Okul öncesi eğitimde dijital hikâye anlatımı üzerine öğretmen görüşleri. Turkish Online Journal of Qualitative Inquiry (TOJQI), 7(1), 175205, 2016. https://doi.org/10.17569/tojqi.87166

[Korat, 2010] Korat, O.: Reading electronic books as a support for vocabulary, story comprehension and word reading in kindergarten and first grade. Computers \& Education, 55, 24-31, 2010. https://doi.org/10.1016/j.compedu.2009.11.014

[Kozminsky, 2013] Kozminsky, E. ve Asher-Sadon, R.: Media type influences preschooler's literacy development: E-book versus printed book reading. Interdisciplinary Journal of ELearning and Learning Objects, 9, 231-245, 2013. https://doi.org/10.28945/1928

[Lin et al., 2015] Lin, L. Y., Cherng, R. J., Chen, Y. J., Chen, Y. J. \& Yang, H. M.: Development effects of television exposure on developmental skills amongyoung children. Infant Behavior \& Development, 38, 20-26, 2015. https://doi.org/10.1016/j.infbeh.2014.12.005 
[Linebarger, 2009] Linebarger, D. L. \& Piotrowski, J. T.: TV as storyteller: How exposure to television narratives impacts at-risk preschoolers' story knowledge and narrative skills. British $\begin{array}{lllll}\text { Journal of Developmental } & \text { Psychology, 27, 47-69, } 2009 .\end{array}$ https://doi.org/10.1348/026151008X400445

[Markman, 2010] Markman, A.: Ulterior motives - How goals seen and unseen drive behaviours. Psychology Today, 2010. https://www.psychologytoday.com/us/blog/ulterior-motives

[Masataka, 2014] Masataka, N.: Development of reading ability is facilitated by intensive exposure to a digital children's picture book. Frontiers in Psychology. 5, 1-5, 2014. https://doi.org/10.3389/fpsyg.2014.00396

[Maureen et al., 2018] Maureen, I. Y., Meij, H. \& Jong, T.: Supporting literacy and digital literacy development in early childhood education using storytelling activities. International Journal of Early Childhood, 50, 371-389, 2018. https://doi.org/10.1007/s13158-018-0230-z

[McCarrick, 2007] McCarrick, K., \& Xiaoming,: Buried treasure: The impact of computer uses on young children's social, cognitive, language development and motivation, AACE Journal, 15(1), 73-95, 2007. https://www.learntechlib.org/p/19982/

[Mendez et al., 2020] Mendez, D., Mendez, M., \& Anguita, J. M.: The effect of digital platforms in the motivation of future primary education teachers towards mathematics. New Trends and Issues Proceedings on Humanities and Social Sciences, 7(3), 112-123, December 2020). https://doi.org/10.18844/prosoc.v7i3.5240

[Mümtaz, 2001] Mümtaz, S.: Children's enjoyment and perception of computer use in the home and the school, Computers \& Education, 36, 347-362, 2001. https://doi.org/10.1016/S03601315(01)00023-9

[Neumann, 2018] Neumann, M. M.: Using tablets and apps to enhance emergent literacy skills in young children. Early Childhood Research Quarterly, 42, 239-246, 2018. https://doi.org/10.1016/j.ecresq.2017.10.006

[Nir-Gal, 2004] Nir-Gal, O. \& Klein, P. S.: Computers for cognitive development in early childhood-the teacher's role in the computer learning environment. Information Technology in Childhood Education Annual, 1, 97-119, 2004. https://www.learntechlib.org/p/12896/

[Nişan, 2017] Nişan, M.: The effect of the early number program on the number concept development of 48-60 months old children (Master's thesis, Adnan Menderes University, Institute of Social Sciences), 2017. https://doi.org/10.13189/ujer.2019.070419

[O’Malley, 1990] O’Malley, J.M. \& Chamot, A.U.: Learning strategies in second language acquisition. Cambridge: Cambridge University Press, 1990. https://tinyurl.com/ygkz48ph

[Olowe, 2014] Olowe, P. K., \& Kutelu, B. O.: Perceived importance of ICT in preparing early childhood education teachers for the new generation children. International Journal of Evaluation and Research in Education (IJERE), 3(2), 119-124, 2014. https://tinyurl.com/yzjfgw9v

[Ozcan, 2018] Ozcan, M.S. \& Kert, S.B.: Technology use and social skills in preschool education in children within some variables (Doctoral dissertation, Kastamonu University), 2018.

[Ozcan, 2020] Ozcan, M\& Kert, S. B.: Use of mobile applications in collocation teaching. Cypriot Journal of Educational Sciences, 15(5), 1176-1190. https://doi.org/10.18844/cjes.v15i5.4629

[Ozyurt, 2017] Ozyurt, G. \& Eliküçük, Ç.: Relation of language features with maternal depression, family functioning, and digital technology usage in children with developmental language delay-comparison with healthy controls. Dusunen Adam The Journal of Psychiatry and Neurological Sciences, 30(4), 299-308., 2017. https://dx.doi.org/10.5350/DAJPN2017300403 
[Qassem, 2020] Qassem, M.: EFL students' perception of the role of teaching novels in enhancing writing skills. Global Journal of Foreign Language Teaching, 10(4), 224-239, 2020. https://doi.org/10.18844/gjflt.v10i4.4994

[Parette et al., 2000] Parette, H. P., Hourcade, J. J., \& Heiple, G. S.: Computers and young children: the important of structured computer experiences for young children with and without disabilities. Early Childhood Education Journal, 27(4);243-250, 2000. https://www.learntechlib.org/p/91857/

[Paterson, 2001] Paterson, B. L., \& Canam, C.: Meta-study of qualitative health research: A practical guide to meta-analysis and meta-synthesis (Vol. 3). Sage, 2001. https://tinyurl.com/ye59wxgw

[Payne et al., 1994] Payne, A. C., Whitehurst, G. J., \& Angell, A. L.: The role of home literacy environment in the development of language ability in preschool children from lowincome families. Early Childhood Research Quarterly, 9, 427-440. 1994. https://doi.org/10.1016/08852006(94)90018-3

[Penuel et al., 2009] Penuel, W. R., Pasnik, S., Bates, L., Townsend, E., Gallagher, L. P., Llorente, C., \& Hupert, N.: "Preschool Teachers Can Use a Media-Rich Curriculum to Prepare Low-Income Children for School Success: Results of a Randomized Controlled Trial." New York: Education Development Center; Menlo Park, CA: SRI International, 2009. https://tinyurl.com/yhmpa7sv

[Plowman, 2007] Plowman, L. \& C. Stephen.: Guided interaction in preschool settings. Journal of Computer Assisted Learning, 23(1): 14-26, 2007. https://doi.org/10.1111/j.13652729.2007.00194.x

[Plowman, 2010] Plowman, L., Stephen, C. \& McPace, J.: Supporting young children's learning with technology at home and in preschool. Research paper in Education, 25, 93-113, 2010. https://doi.org/10.1080/02671520802584061

[Primavera et al., 2001] Primavera, J., Wiederlight, P.P., \& DiGiacomo, T. M.: "Technology access for low-income preschoolers: bridging the digital divide." Paper presented at the American Psychological Association Annual Meeting, in San Francisco, 2001. https://tinyurl.com/yhovc8zu

[Şahin, 2006] Şahin, B.: Computer-assisted science teaching and its effects in preschool period. Unpublished master's thesis, Yeditepe University Institute of Social Sciences, Istanbul, 2006.

[Şalc1, 2018] Şalcı, O. Karakaya, K., \& Tatlıeşme, S.: Evaluation of the Effect of Using Smart Devices on the Development of 3-6 Years Old Children in Terms of Preschool Teachers' Views, Karabuk Universitesi, Sosyal Bilimler Enstitusu Dergisi (4) 53-63, 2018. http://www.inased.org/epasad/v15n3/epasrv15n3.pdf\#page=100

[Saleem et al., 2012] Saleem, M., Anderson, C. A., \& Gentile, D. A.: Effects of prosocial, neutral, and violent video games on college students' affect. Aggressive Behaviour, 38, 281-287, 2012. https://doi.org/10.1002/ab.21428

[Sandelowski et al., 1997] Sandelowski, M., Docherty S., \& Emden C.: Qualitative metasynthesis: Issues and techniques. Research in Nursing and Health, 20, 365-371, 1997. https://doi.org/10.1002/(SICI)1098-240X(199708)20:4\%3C365::AID-NUR9\%3E3.0.CO;2-E

[Sedliacik, 2017] Sedliacik, I., \& Dadob, J.: Unintended Consequences of Interventions in Electricity Production and Consumption. New Trends and Issues Proceedings on Humanities and Social Sciences, 3(4), 16-22, 2017. https://doi.org/10.18844/gjhss.v3i4.1509 
[Skau, 2006] Skau, L., \& Cascella, P. W.: Using assistive technology to foster speech and language skills at home and in preschool. Teaching Exceptional Children, 38(6): 12-17, 2006. https://doi.org/10.1177\%2F004005990603800602

[Sung et al., 2016] Sung, Y. T., Chang, K. E., \& Liu, T. C.: The effects of integrating mobile devices with teaching and learning on students' learning performance: A meta-analysis and research synthesis. Computers \& Education, 94: 252-275, 2016. https://doi.org/10.1016/j.compedu.2015.11.008

[Tabors, 2001] Tabors, P. O., Roach, K. A., \& Snow, C. E.: Home language and literacy environment: Final results. In D.K. Dickinson \& P.O. Tabors (Eds.), Beginning language with literacy: Young children learning at home and at school (pp. 111-138). Baltimore: Paul H. Brookes, 2001. https://psycnet.apa.org/record/2001-06306-005

[Tavasoli et al., 2020] Tavasoli, M. R., Mowlaie, B., Majid, M. A., \& Rahimi, A.: The comparative effects of different gloss types through screencast on vocabulary learning and working memory of Iranian EFL learners. International Journal of New Trends in Social Sciences, 4(1), 10-24, 2020. https://doi.org/10.18844/ijntss.v4i1.4809

[Teepe et al., 2016] Teepe, R. C., Molenaar, I. \& Verhoeven, L.: Technology-enhanced storytelling stimulating parent-child interaction and preschool children's vocabulary knowledge. Journal of Computer Assisted Learning, 33(2), 1-14, 2016. https://doi.org/10.1111/jcal.12169

[Thalheimer, 2002] Thalheimer, W. \& Cook, S.: How to calculate effect sizes from published research: A simplified methodology. Work-Learning Research, 1-9, 2002. http://www.worklearning.com/effect_sizes.htm

[Toki, 2010] Toki, E. I., \& Pange, J.: E-learning activities for articulation in speech language therapy and learning for preschool children. Procedia Social and Behavioral Sciences, 2: 4274 4278, 2010. https://doi.org/10.1016/j.sbspro.2010.03.678

[Tomopoulous et al., 2006] Tomopoulous, S., Dreyers, B. P., Tamis-LeMonda, C.S., Flynn, V., Rovira, I., \& Tineo, W.: Books, toys, parent-child interaction and development in young Latino children. Ambulatory Pediatrics, 6, 72-78, 2006. https://doi.org/10.1016/j.ambp.2005.10.001

[Topping et al., 2011] Topping, K. J., Dekhinet, R., \& Zeedyk, S.: Hindrances for parents in enhancing child language. Educational Psychology Review, 23(3), 413-455, 2011. http://dx.doi.org/10.1007\%2Fs10648-011-9169-4

[Ulubey, 2005] Ulubey, Ö., \& Aykaç, N.: The reflection of the primary programs of 2005 educational philosophy of the proclamation of the Republic of Turkey. Mersin University Journal of Education Faculty, 2005. https://dergipark.org.tr/en/pub/cuefd/issue/4136/54293

[Varhallen, 2009] Varhallen, M. J. A. J. \& Bus, A. G.: Video storybook reading as a remedy for vocabulary deficits outcomes and processes. Journal for Educational Research Online, 1(1), 172196, 2009. https://www.proquest.com/docview/1011090096?pqorigsite $=$ gscholar $\&$ fromopenview $=$ true

[Varhallen, 2020] Varhallen, M. J. A. J. \& Bus, A. G.: Low-1ncome 1mmigrant pupils learning vocabulary through digital picture storybooks. Journal of Educational Psychology, 102(1), 5461, 2020. https://psycnet.apa.org/doi/10.1037/a0017133

[Varhallen et al., 2006] Varhallen, M. J. A. J., Bus, A. G. \& Jong, M. T.: The promise of multimedia stories for kindergarten children at risk. Journal of Educational Psychology, 98(2), 410-419, 2006. https://psycnet.apa.org/doi/10.1037/0022-0663.98.2.410 
[Walter-Laager et al., 2016] Walter-Laager, C., Brandenberg, K., Tinguely, L., Schwarz, J., Pfiffner, M. R. \& Moschner, B.: Media-assisted language learning for young children: Effects of a word-learning app on the vocabulary acquisition of two-year-olds. British Journal of Educational Technology, 48(4), 2016. https://doi.org/10.1111/bjet.1247;2

[Yakubu et al., 2018] Yakubu, M. B., Hassan, A., Ahmad, A., Musa, K. I., \& Gital, A. Y. Mobile learning stimulus in Nigeria. Global Journal of Information Technology: Emerging 8(3), $95-101$, 2018. https://pdfs.semanticscholar.org/155a/bbe15f143f27d3f787df2bd8ca663aa6aaba.pdf

[Yüksel et al., 2014] Yüksel, M., Kucukoglu, E. K., Unsal, F. O. \& Salli, D: The development and implementation of a guidance counseling program aiming to support 54-66 months old children's development level and readiness for primary school, International Journal on New Trends in Education and Their Implications, 5(3), 13-25, 2014. https://tinyurl.com/yer8s3cg 